\title{
Focus on the supramolecular structure of milk fat in dairy products
}

\author{
Christelle LOPEZ* \\ UMR Science et Technologie du Lait et de l'EEuf, INRA-Agrocampus, \\ 65 rue de Saint-Brieuc, 35042 Rennes Cedex, France
}

\begin{abstract}
Bovine fat is dispersed in raw milk as natural milk fat globules, with an average diameter of $4 \mu \mathrm{m}$, which are enveloped in a biological membrane, the milk fat globule membrane (MFGM). However, dairy processes modify the supramolecular structure and the surface composition of milk fat. Thus, milk fat is present in many dairy products under various forms. In this study, we focused on the fact that natural milk fat globules are rarely consumed in their native state, i.e. in fresh raw milk. In most drinking milks, fat globules are homogenised in order to avoid their rising at the surface of the products. Furthermore, fat globules are heat treated to avoid the growth of micro-organisms. As a consequence of the technological process applied, the volume-weighted average diameter of fat globules in drinking milks is in the range $0.2-0.5 \mu \mathrm{m}$. Homogenisation of fat globules led to the partial disruption of the MFGM and to the adsorption of milk proteins. Moreover, this study showed that in cheeses, milk fat can be dispersed as (i) fat globules with the MFGM, (ii) aggregates of fat globules, (ii) homogenised fat globules, (iii) free fat and (iv) a combination of different phases and structures. The knowledge of the supramolecular structure of milk fat in dairy products is of primary importance regarding its technological, sensorial and nutritional properties.
\end{abstract}

milk fat / microstructure / confocal laser scanning microscopy

\section{INTRODUCTION}

Milk fat is widely consumed in different kinds of products, i.e., milk, cream, icecream, yoghurt, cheese, butter and as anhydrous milk fat (AMF). Its concentration and chemical composition are easily determined and thus well-known. However, information on the supramolecular structure of milk fat in dairy products is scarce.

Milk, which is the secretion of the mammary gland, is a staple food for all young mammals [1]. It is important to highlight that directly consumed from the mother to the newborn, all the constituents of milk, mainly proteins and fat, are in their native state. Depending on the species considered (humans, bovine, sheep, goats, etc.), milk has special characteristics, i.e. composition and structure of the constituents [2, 3]. Although milk is an important product, regarding the high nutritive value of its constituents, mammals usually do not consume it post weaning. However, bovine milk and dairy products are widely used for human consumption.

Bovine milk consists of $87 \%$ water, [4]. Fat is a major component of fresh raw milk

\footnotetext{
* Corresponding author: Christelle.Lopez@rennes.inra.fr
} 
that exists as small droplets called the milk fat globules. The size of natural milk fat globules ranges from 0.2 to $15 \mu \mathrm{m}$ with a volume-weighted diameter of about $4 \mu \mathrm{m}$ depending on cow breed and season [5]. They are composed mainly of $98 \%$ triacylglycerols, at least 200 of which have been identified [3,6]. Natural milk fat globules are surrounded by a biological membrane, the milk fat globule membrane (MFGM). The native MFGM consists of a complex mixture of proteins, glycoproteins, enzymes, phospholipids, cholesterol and other minor components [7]. The structure in trilayer, thickness $(\sim 10 \mathrm{~nm})$ and composition of the native MFGM depends on the secretion process [8-10]. The MFGM acts as a natural emulsifying agent that prevents aggregation and coalescence of milk fat and also protects the fat against enzymatic action, mainly lipolysis [11].

During the processing of milk, several treatments may alter the natural structure of fat globules and the MFGM: (i) mechanical treatments, i.e. pumping, agitation and homogenisation, (ii) thermal treatments, i.e. refrigeration and heating (pasteurisation, sterilisation) and (iii) enzymatic treatments, i.e. lipolysis. It is well known that heat treatments and homogenisation produce the greatest changes in the milk fat globules. Heat treatment of milk causes changes in the MFGM by promoting interactions between milk proteins and native MFGM components $[12,13]$. Homogenisation of milk causes a reduction of fat globule size and a concurrent increase in the milk fat surface area, which alters the native MFGM and modifies the composition of the membrane [11, $12,14]$.

However, the effects of physico-chemical and physical treatments applied during the manufacture of dairy products on the changes in milk fat globule supramolecular structure have not been fully studied. Few studies exist on the organisation of fat in cheese [15-19].

In France, the consumption of milk, butter and cheese is an everyday act with a strong cultural dimension. Thus, milk and dairy products are of great economical importance. About 23 million tons of milk and 1 million tons of milk fat are produced each year [20]. Considering the production of milk and the concentration of fat in milk, we can calculate that in 2001, milk fat was mainly present in the form of butter and anhydrous milk fat $(360000 \mathrm{t})$, cheese $(340000 \mathrm{t})$ and cream (100 $000 \mathrm{t})$. French people consume about $13.5 \mathrm{~kg}$ milk fat $/$ person/year: mainly as butter $(6.6 \mathrm{~kg}$ fat/person/year) and ripened cheese $(3.6 \mathrm{~kg}$ fat/ person/year). Regarding the consumption of cheese, France is the second country in the world with $24.5 \mathrm{~kg} /$ person/year. The exceptional variety of cheese produced in France is accompanied by a diverse array of cheese-making techniques.

Milk fat is widely consumed. However, health authorities in most Western nations have drawn links between fat consumption and chronic conditions such as heart disease and obesity, resulting in widespread recommendations for reductions in the consumption of saturated fats and cholesterol [21]. Regarding the role of milk fat in dairy products, Jaros et al. [22] found that the texture, flavour and physico-chemical properties of cheese are greatly governed by the milk fat. Thus, the structure of fat in dairy products is of tremendous importance regarding technological, functional, sensorial and nutritional properties.

The objective of this work was to show that the supramolecular structure of milk fat in dairy products can be drastically different, depending on the technological process applied during the manufacture. We focused on the organisation of fat in raw milk, drinking milks and on the supramolecular structure of fat in different kinds of cheeses.

\section{MATERIAL AND METHODS}

\subsection{Samples}

The raw whole milk (3.8 $\mathrm{g}$ fat $/ 100 \mathrm{~g}$ ) used in this study was obtained from a local dairy 
plant (Triballat, Noyal-sur-Vilaine, France). Full-fat UHT milk ( $3.6 \mathrm{~g}$ fat $\left.100 \mathrm{~g}^{-1}\right)$, semiskimmed UHT milk (1.55 g fat $\left.100 \mathrm{~g}^{-1}\right)$, skimmed UHT milk $\left(0.1 \mathrm{~g}\right.$ fat $\left.100 \mathrm{~g}^{-1}\right)$, full-fat pasteurised milk ( $3.5 \mathrm{~g}$ fat $100 \mathrm{~g}^{-1}$ ) and semi-skimmed pasteurised milk (1.5 g fat $100 \mathrm{~g}^{-1}$ ) were commercial products, purchased from a local supermarket (Géant, Rennes, France).

Camembert and ultrafiltration cheeses (soft cheeses) and whipped cream cheese were commercial cheeses, obtained as samples submitted for routine quality control analysis.

The samples characterised during the manufacture of Emmental cheese (hard cooked cheese) were obtained as follows: cheese milk was coagulated at $31^{\circ} \mathrm{C}, \mathrm{pH} 6.62$, the rennet-induced gel was cut, stirred and heated to $51{ }^{\circ} \mathrm{C}$ for $20 \mathrm{~min}$, before being drained in the vat, resulting in curd grains of about the same size as rice: length $4-6 \mathrm{~mm}$. These curd grains were maintained under pressure $(0.4 \mathrm{kPa})$, at $47^{\circ} \mathrm{C}$, during $4 \mathrm{~h}$. Then, the curd was demoulded and placed in a cold brine bath for $48 \mathrm{~h}$. The cheese was ripened during $52 \mathrm{~d}$ [23].

\subsection{Milk fat globule size measurements}

The fat globule size distribution was measured by laser light scattering using a Mastersizer 2000 (Malvern, UK), with two laser sources. The refractive indexes used were 1.458 and 1.460 for milk fat at 633 and $466 \mathrm{~nm}$, respectively, and 1.33 for water. The samples of milk (about $0.2 \mathrm{~mL}$ ) were diluted in $100 \mathrm{~mL}$ of water directly in the measurement cell of the apparatus in order to reach $10 \%$ obscuration. The casein micelles were dissociated by adding $1 \mathrm{~mL}$ of $35 \mathrm{mM}$ EDTA/NaOH, pH 7 buffer to the milks, in the apparatus. In order to determine the size of fat globules in the renneted gel, $1 \mathrm{~g}$ of the sample was dissociated with $5 \mathrm{~mL}$ of dissociation buffer ( $6 \mathrm{~mol} \cdot \mathrm{L}^{-1}$ urea, $100 \mathrm{mmol} \cdot \mathrm{L}^{-1}$ EDTA, $20 \mathrm{mmol} \cdot \mathrm{L}^{-1}$ imidazole buffer $\mathrm{pH}$ 6.6), and stirred for $30 \mathrm{~min}$ at room temperature prior to measurement. The size dis- tribution of fat globules were characterised by the volume-weighted average diameter $d_{43}$ defined as $\Sigma n_{\mathrm{i}} d_{\mathrm{i}}^{4} / \Sigma n_{\mathrm{i}} d_{\mathrm{i}}{ }^{3}$, where $n_{\mathrm{i}}$ is the number of fat globules of diameter $d_{\mathrm{i}}$. This parameter is very sensitive to the presence of small amounts of large particles. The specific surface area $S=6 . \varphi / d_{32}$, where $\varphi$ is the volume fraction of milk fat and $d_{32}$ is the volume/surface average diameter defined as $\Sigma n_{\mathrm{i}} d_{\mathrm{i}}^{3 / \Sigma} n_{\mathrm{i}} d_{\mathrm{i}}^{2}$, was calculated. The size distribution width, Span $=\left(d_{\mathrm{v} 0.9}-d_{\mathrm{v} 0.1}\right) /$ $d_{\mathrm{v} 0.5}$, where $d_{\mathrm{v} 0.9}$ is the diameter below which lie $90 \%$ of the globule volume, and respectively $10 \%$ for $d_{\mathrm{v} 0.1}$ and $50 \%$ for $d_{\mathrm{v} 0.5}$ was calculated. The fraction $\Phi$ (expressed in percent) of the milk fat globule surface that is covered by milk proteins after processing of commercial milks was calculated as follows: $\Phi=[(\mathrm{Sf}-\mathrm{Si}) / \mathrm{Sf}] \cdot 100$, where Sf is the specific surface area of milk fat globules after processing and $\mathrm{Si}$ is the natural milk fat globule specific surface area calculated from the fat globule size distribution of raw milk.

The fat globule size distribution was observed by light microscopy using an Olympus B×51 microscope.

\subsection{Microstructure of cheese}

The supramolecular structure of milk fat at different stages during the manufacture of Emmental cheese and in different kinds of cheeses was examined using confocal laser scanning microscopy (CLSM). Thin slices of samples, measuring approximately $5 \mathrm{~mm} \times 5 \mathrm{~mm} \times 3 \mathrm{~mm}$ thick, were prepared from the freshly cut samples, using a scalpel. The fat was stained using a lipid-soluble Nile Red fluorescent dye (SigmaAldrich, St Louis, USA). The protein network was stained using Acridine Orange fluorescent dye (Aldrich Chemical Company, Inc., Milwaukee, USA). Each slice of samples was placed between a microscope slice and a cover slip. The sample slices were thus incubated with the stains for $30 \mathrm{~min}$ in the dark at $4{ }^{\circ} \mathrm{C}$. Microstructural analysis was made using a confocal Leica 


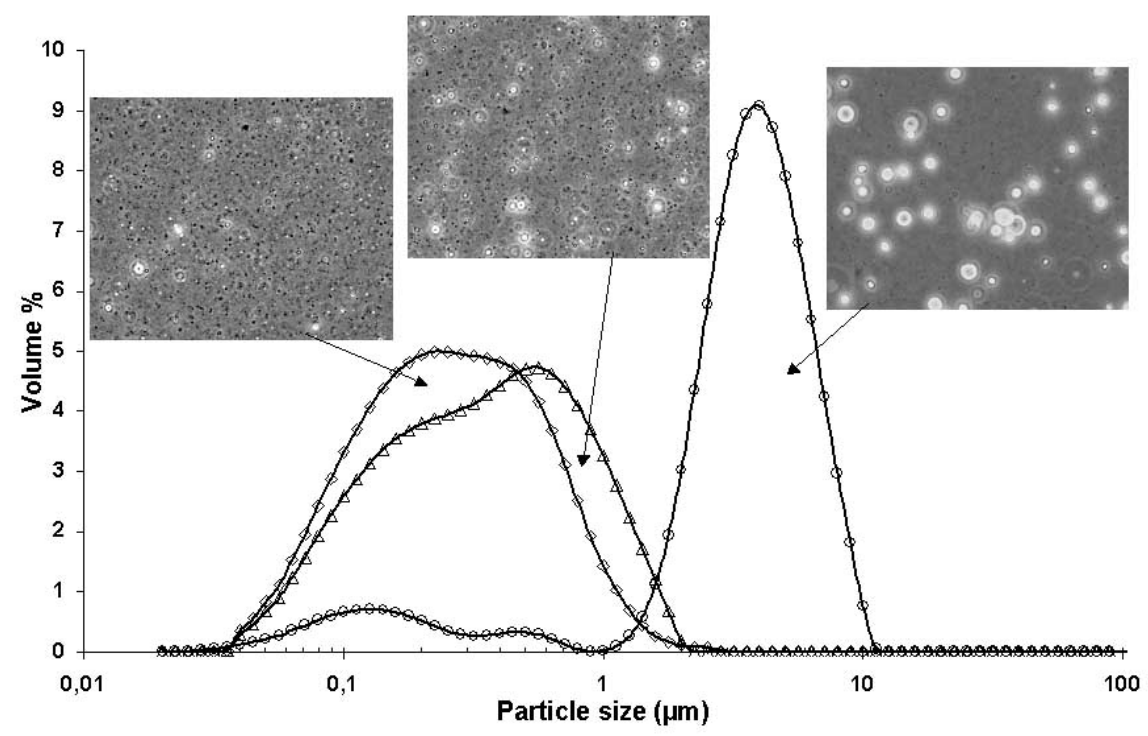

Figure 1. Milk fat globule size distribution in full-fat raw milk (o), full-fat UHT milk $(\Delta)$ and fullfat pasteurised milk $(\diamond)$, measured by laser light scattering. The light micrographs corresponding to the different milks are identified on the figure.

TCS NT microscope (Leica, Microsystems, Heidelberg, Germany), which employed an argon/krypton laser in a dual-beam fluorescent mode, with excitation wavelengths of $568 \mathrm{~nm}$ and $488 \mathrm{~nm}$ for fat and protein, respectively. The two-dimensional images had a resolution of $1024 \times 1024$ pixels and the pixel scale values were converted into micrometers using a scaling factor.

\section{RESULTS}

\subsection{On the size distribution of fat globules in fresh raw milk and drinking milks}

Figure 1 shows the size distribution of milk fat globules in full-fat raw milk, fullfat pasteurised milk and full-fat UHT milk determined by laser light scattering and observed by light microscopy. Particle size distribution parameters of the fat globules are presented in Table I. The size of natural fat globules dispersed in raw milk ranges from 0.03 to about $11 \mu \mathrm{m}$, with two small peaks at 120 and $500 \mathrm{~nm}$ and a main peak centred at $4 \mu \mathrm{m}$. Thus, the size distribution of native milk fat globules is polydispersed and multimodal. The volume-weighted diameter of natural fat globules in raw milk is $4.07 \mu \mathrm{m}$. In the full-fat UHT and full-fat pasteurised milks, the size of milk fat globules range from 0.03 to $2-3 \mu \mathrm{m}$ with a volume-weighted diameter around $0.4-0.5 \mu \mathrm{m}$ (Tab. I). The shape of the size distribution changed markedly between raw and heattreated milks, with the disappearance of the peak centred at about $4 \mu \mathrm{m}$. Furthermore, the latter results show that the size of fat globules was lower in drinking milks compared to the size of natural milk fat globules in raw milk. For a given concentration of fat in the milk, decreasing the diameter of fat globules from 4 to $0.4-0.5 \mu \mathrm{m}$ (10 to 12 fold), corresponded to an increase of the number of fat globules with a multiplicative factor of 1000 to 1700 . Thus, the specific surface area (S) of fat globules was larger for fullfat drinking milks than for raw milk; $S$ 
Table I. Fat concentration and physical characteristics of raw and commercial milks. Parameters of the size distribution of natural and processed milk fat globules determined from raw and commercial milks: $d_{43}=$ volume-weighted average diameter; Span = size distribution width; $S=$ specific surface area. Fraction $(\Phi)$ of the milk fat globule surface that is covered by milk proteins after processing of commercial milks.

\begin{tabular}{|c|c|c|c|c|c|c|}
\hline \multirow{2}{*}{$\begin{array}{l}\text { Samples } \\
\text { Heat treatment }\end{array}$} & \multirow[b]{2}{*}{ Fat content } & \multirow{2}{*}{$\begin{array}{c}\text { Fat } \\
\text { concentration } \\
\mathrm{g} \cdot 100 \mathrm{~g}^{-1}\end{array}$} & \multicolumn{3}{|c|}{ Size distribution parameters } & \multirow{2}{*}{$\begin{array}{c}\Phi \\
(\%)\end{array}$} \\
\hline & & & $\begin{array}{l}d_{43} \S \\
(\mu \mathrm{m})\end{array}$ & Span & $\begin{array}{c}S^{\S} \\
\left(\mathrm{m}^{2} \cdot \mathrm{g}^{-1} \text { fat }\right)\end{array}$ & \\
\hline Raw milk & Full fat & 3.8 & $4.07 \pm 0.01$ & 1.66 & $7.1 \pm 0.3$ & - \\
\hline Pasteurised milk & Full fat & $3.5^{*}$ & $0.37 \pm 0.01$ & 2.43 & $33.2 \pm 0.4$ & 78.6 \\
\hline Pasteurised milk & Semi-skimmed & $1.5^{*}$ & $0.26 \pm 0.01$ & 2.21 & $41.3 \pm 0.3$ & 82.8 \\
\hline UHT milk & Full fat & $3.6^{*}$ & $0.49 \pm 0.02$ & 2.61 & $27.9 \pm 0.3$ & 74.6 \\
\hline UHT milk & Semi-skimmed & $1.55^{*}$ & $0.71 \pm 0.01$ & 2.17 & $20.9 \pm 0.6$ & 66.0 \\
\hline UHT milk & Skimmed & $0.1 *$ & $0.17 \pm 0.02$ & 1.77 & $56.0 \pm 0.4$ & 87.3 \\
\hline
\end{tabular}

* Value indicated in the package of commercial milk. ${ }^{\S} n=3$.

increased from about 7 to $28-33 \mathrm{~m}^{2} \cdot \mathrm{g}^{-1}$ fat (Tab. I). Furthermore, the fraction $\Phi$ of the milk fat globule surface that is covered by milk proteins after processing of commercial milks was calculated; it corresponded to $74.5 \%$ for UHT full-fat milk and $78.6 \%$ for pasteurised full-fat milk (Tab. I), meaning that about $25 \%$ of the newly formed surface of milk fat globules may have been covered by the MFGM. This increase in the surface of milk fat globules and the change in the composition of the interface are important considering chemical and enzymatic reactions which occur at the interface, such as lipolysis of triacylglycerols and thus the digestibility of fat globules.

Figure 2 shows the size distribution of fat globules in UHT and pasteurised milks as a function of fat concentration. Particle size distribution parameters of the fat globules are presented in Table I. Regarding UHT milks, the size distribution of fat globules ranged from 0.03 to $2-2.5 \mu \mathrm{m}$ in full-fat and semi-skimmed milks, with a volumeweighted diameter of $0.5-0.7 \mu \mathrm{m}$ respectively (Fig. 2A). In the skimmed milk, which contained $0.1 \mathrm{~g}$ fat $\cdot 100 \mathrm{~g}^{-1}$, the size of fat globules ranged from 0.03 to $2 \mu \mathrm{m}$ with a volume-weighted diameter of $0.17 \mu \mathrm{m}$ (Fig. 2A). In the pasteurised milks, the size of fat globules ranged from 0.03 to $1 \mu \mathrm{m}$ for semi-skimmed milk and to $2 \mu \mathrm{m}$ for full-fat milk (Fig. 2B). The difference observed between full-fat and semi-skimmed milks may have been induced by physical treatments applied during the process, i.e. skimming and standardisation in fat, which may have led to coalescence of fat globules.

\subsection{On the supramolecular structure of milk fat in cheese}

This study shows that the supramolecular structure of milk fat in cheese is greatly influenced by the technological process applied. We focused on the impact of the heat and mechanical treatments on the organisation of milk fat during the manufacture of the most widely consumed hard cheese in France: Emmental cheese. Furthermore, the microstructures of different kinds of cheeses were characterised. The supramolecular structure of fat in a complex matrix such as cheese was observed using confocal laser scanning microscopy (CLSM).

\subsubsection{Influence of heat and mechanical treatments on the organisation of milk fat in a complex matrix}

Changes in the structure of milk fat globules due to heat treatment of the curd grains 

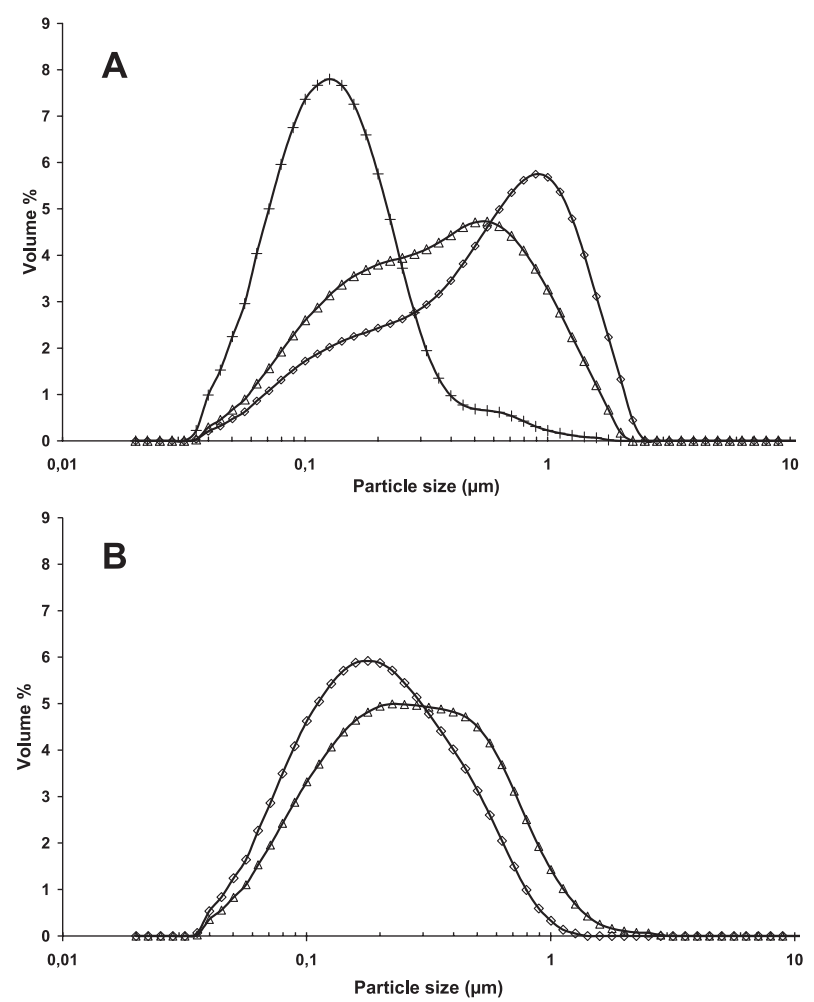

Figure 2. Milk fat globule size distribution in (A) full-fat $(\Delta)$ semi-skimmed $(\diamond)$ skimmed $(+)$ UHT milks and (B): full-fat $(\Delta)$ and semi-skimmed $(\diamond)$ pasteurised milks.

during the manufacture of Emmental cheese were particularly studied (Fig. 3).

Figure 3A shows the microstructure of the rennet-induced gel formed during the early stage of the manufacture of Emmental cheese. Considering the physico-chemical characteristics of the gel, the total solid content was $116 \mathrm{~g} \cdot \mathrm{kg}^{-1}$, with $28.5 \mathrm{~g} \cdot \mathrm{kg}^{-1}$ of fat and $33.6 \mathrm{~g} \cdot \mathrm{kg}^{-1}$ of total protein. The micrograph shows the continuous network formed by casein micelles after their coagulation and reveals the porous structure of the gel in which the fat globules are entrapped. The fat globules are spherical individual particles. The size of fat globules in the gel was measured after dissociation of the casein matrix, as detailed in the material and methods section. The size of fat globules observed by CLSM was in agreement with laser light scattering experiments which calculated a mean volume-weighted diameter of $4.47 \pm$
$0.06 \mu \mathrm{m}$ (Fig. 4). The size of the milk fat globules entrapped in the gel was larger than that of native milk fat globules in raw milk, meaning that coalescence occurred during the preparation and coagulation of the milk (Tab. I). Milk fat globules are mainly located in the serum pores of the casein network. It is important to highlight that such a rennet-induced gel is the starting point in the manufacture of many kinds of cheeses.

After coagulation, the rennet-induced gel characterised in Figure 3A was cut and heated from $32{ }^{\circ} \mathrm{C}$ to $51^{\circ} \mathrm{C}$ during $20 \mathrm{~min}$. Figure 3B shows the microstructure of the curd grain after heating. The micrograph clearly shows that heating of the rennetinduced gel induced the aggregation of milk fat globules. The aggregates observed on the micrograph were formed by 2 to 4 fat globules. Their size did not exceed $10 \mu \mathrm{m}$. 

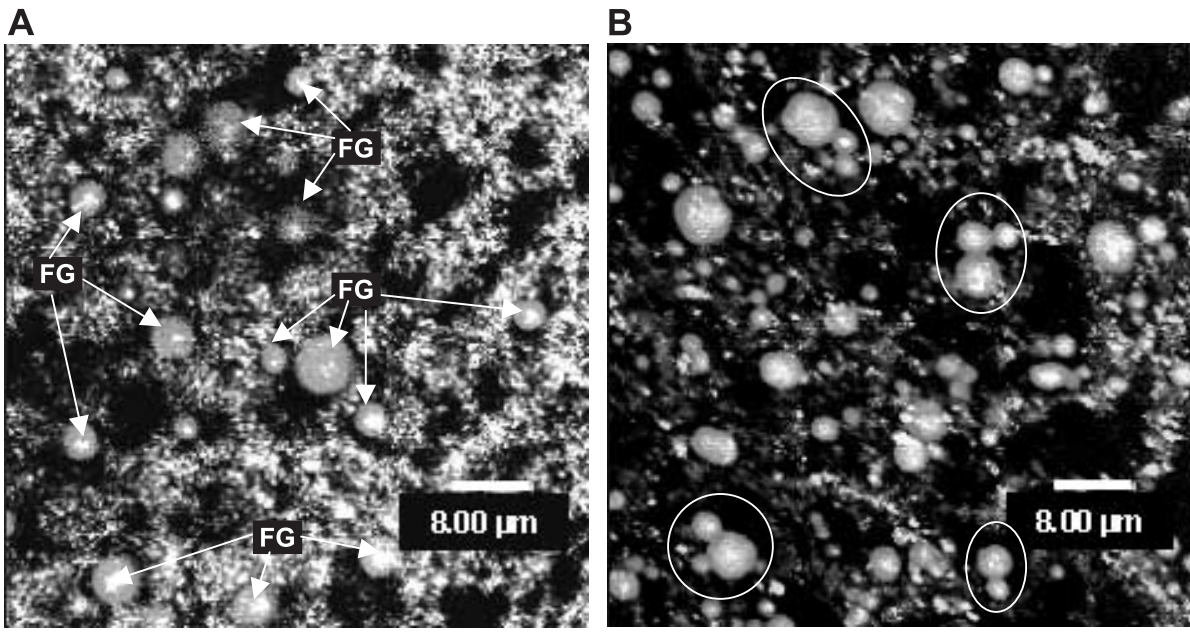

Figure 3. Confocal laser scanning micrographs taken during the manufacture of Emmental cheese: (A) rennet-induced gel before heating, (B) curd grain after heating $\left(51^{\circ} \mathrm{C}, 20 \mathrm{~min}\right)$. FG: fat globules. The fat globule aggregates are circled.

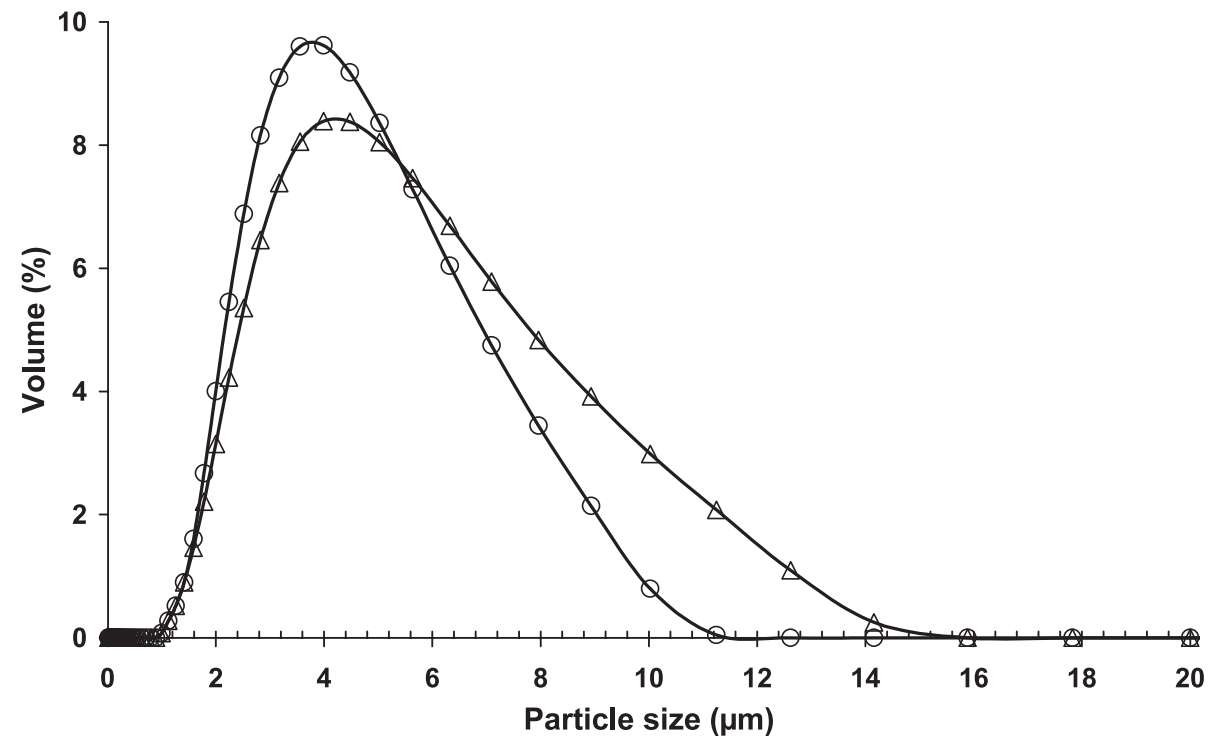

Figure 4. Milk fat globule size distribution in rennet-induced gel before heating (o) and in a curd grain after heating $(\Delta)$, measured by laser light scattering.

Aggregation of fat globules may favour their coalescence, e.g. fusion between fat globules, by increasing the time in which they are in contact.
The comparison between the size distribution of fat globules before and after the heat treatment is presented in Figure 4. The increase in fat globule size was quantified 
A

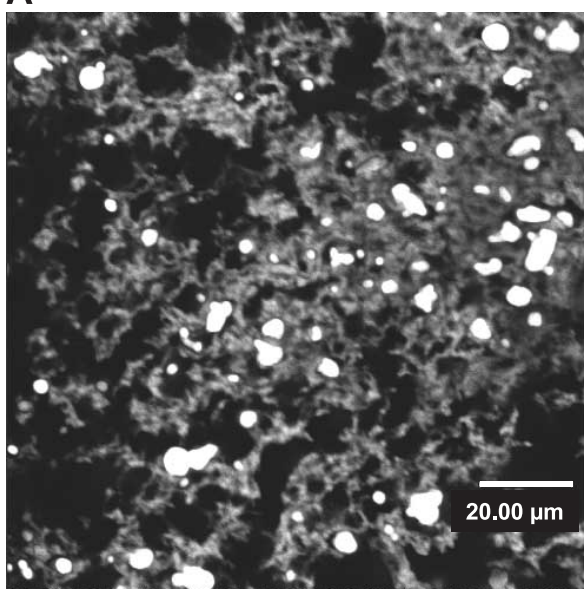

B

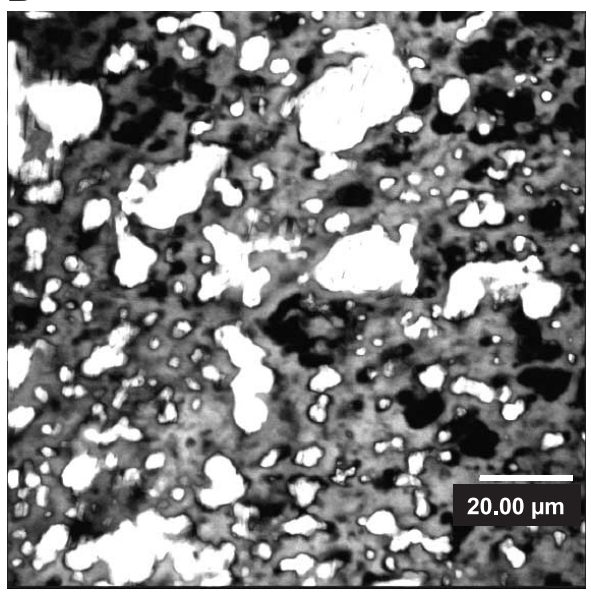

Figure 5. Confocal laser scanning micrographs of (A) the heated curd grains before pressing and (B) the curd grains of Emmental cheese after pressing $\left(47^{\circ} \mathrm{C}, 0.4 \mathrm{kPa}, 4 \mathrm{~h}\right)$. Fat appears as bright areas, protein network appears as grey levels.

by laser light scattering. The volume-weighted diameter increased from $4.47 \pm 0.06 \mu \mathrm{m}$ to $5.18 \pm 0.1 \mu \mathrm{m}$.

This study shows that the heat treatment $\left(51^{\circ} \mathrm{C}\right)$ of a rennet-induced gel modifies the supramolecular structure of milk fat globules by inducing their aggregation and their coalescence. As all oil in water emulsions, milk is submitted to physical instabilities.

Many different mechanical treatments may be applied to milk, coagulum and curd grains during the manufacture of cheeses. In this study, we focused on the pressing stage applied to curd grains during the manufacture of hard cheeses.

Figure 5A shows the microstructure of a heated curd grain. In this micrograph, the fat appears as bright areas, the protein network as grey and the serum phase as black. The fat globules are entrapped in the casein matrix. They do not correspond to individual spherical particles but rather to aggregates of milk fat globules. Figure 5B shows the microstructure of Emmental cheese after pressing. This mechanical treatment results in large changes in the composition and the structure of the curd grains. The total solid content increased from $401.9 \pm 4.8$ to $569.8 \pm$ $2.6 \mathrm{~g} \cdot \mathrm{kg}^{-1}(+30 \%)$, as a result of whey removal. Compared with Figure 5A, the density of the protein network and fat increased. This can be explained as follows: after pressing of curd grains, the volume of Emmental cheese decreased as a result of the compaction of curd grains. Moreover, dry matter increased from 402 to $570 \mathrm{~g} \cdot \mathrm{kg}^{-1}$. Briefly, after the pressing of curd grains, the Emmental cheese microstructure consisted of cavities containing fat globules and a serum phase, surrounded by protein strands. This micrograph clearly shows the disruption of milk fat globules under pressure. The MFGM rupture and the absence of the MFGM around fat were not directly measured in this study, but the change in the shape and the increase in the size of fat globules observed may correspond to the formation of free fat, which is the fat not protected by the MFGM. Thus, after pressing, fat is present in the casein matrix of Emmental cheese under different surpamolecular forms: (i) individual milk fat globules, which have a similar size as in cheese milk $(\sim 4 \mu \mathrm{m})$, (ii) aggregates of fat globules, (iii) coalesced fat globules and (iv) non-globular 
fat, also called free fat. The parameters implicated in the deformation, rupture and coalescence of milk fat globule fat under pressure are discussed in Lopez et al. [23].

\subsubsection{Comparison of the supramolecular structure of fat in different kinds of cheeses}

The microstructure of cheese is influenced by the chemical composition and the technological process applied during the manufacture. Figure 6 shows the microstructure of different kinds of cheeses observed using CLSM. In all the micrographs, the fat is coloured in red and the proteins appear in grey levels.

Figure 6A corresponds to the microstructure of the most widely manufactured hard cheese in France, which is Emmental cheese. Three main supramolecular structures
A

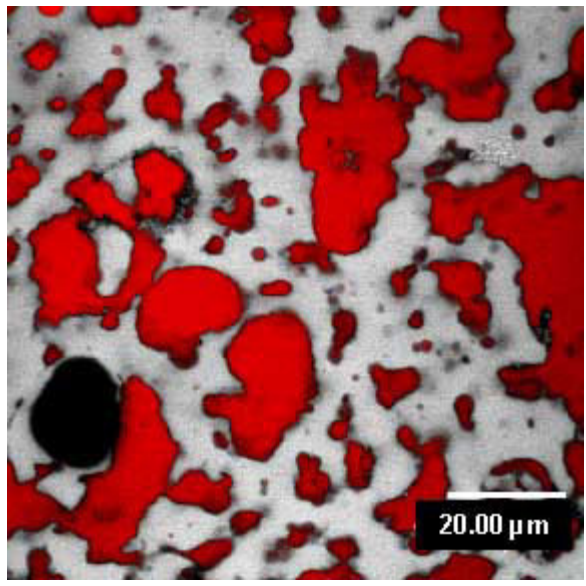

C

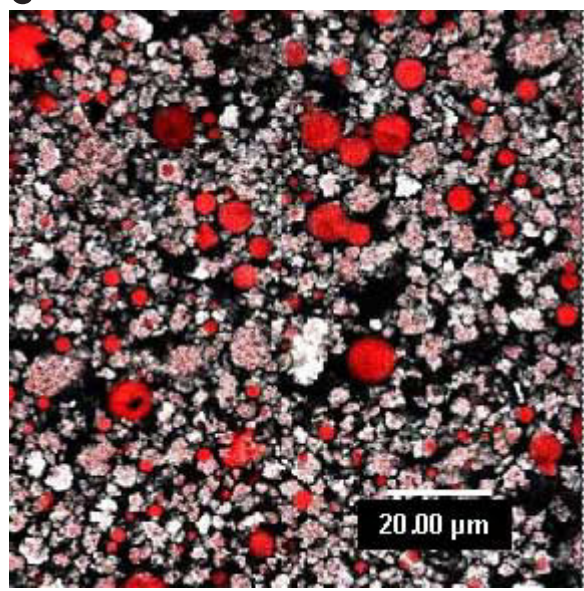

B

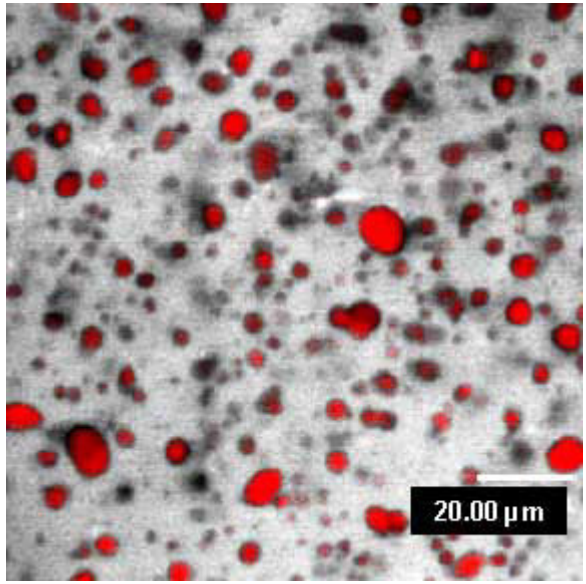

D

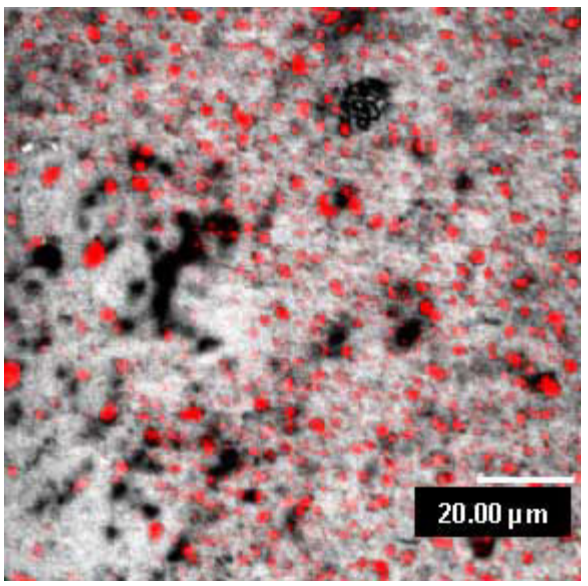

Figure 6. Confocal laser scanning micrographs of different kinds of cheeses: (A) Emmental cheese (B) Camembert cheese (C) whipped cream cheese (D) soft cheese made with ultrafiltration techno$\operatorname{logy}$. Fat is coloured in red, proteins are in grey levels. Black areas correspond to serum or gas holes. 
of milk fat are observed: (i) large non-globular inclusions of fat resulting from the disruption of MFGM and allowing free triacylglycerols to fill voids in the protein matrix, (ii) aggregates of partially disrupted fat globules and (iii) small fat globules which may be enveloped by the MFGM (23). The casein network separating the fat inclusions may form impermeable barriers preventing the coalescence of fat. The black hole corresponds to a pocket of gas, which is characteristic of propionic acid fermentation, leading to the formation of the "eyes" in Emmental cheese. The chemical composition of the Emmental cheese characterised in this study was: $298 \mathrm{~g} \cdot \mathrm{kg}^{-1}$ fat, $276 \mathrm{~g} \cdot \mathrm{kg}^{-1}$ protein and $628 \mathrm{~g} \cdot \mathrm{kg}^{-1}$ dry matter.

Figures $6 \mathrm{~B}$ and $6 \mathrm{D}$ show the microstructure of two different soft cheeses. Figure 6B shows the microstructure of Camembert cheese, manufactured with traditional technology. Fat is dispersed as fat globules with a size distribution larger than the size of natural milk fat globules. These results mean that the heat and mechanical treatments applied during the manufacture of Camembert cheese induced some coalescence of fat globules. Furthermore, aggregates of fat globules were observed. Figure 6D shows the microstructure of a low-fat soft cheese made with the ultrafiltration (UF) technology. Fat is dispersed as small fat globules, $\sim 0.5-1 \mu \mathrm{m}$, meaning that homogenisation was used during the process. Homogenisation of milk induced (i) a decrease of milk fat globule size and (ii) changes in the composition of the fat globule surface with the adsorption of milk proteins, mainly caseins. As a consequence, the fat globules may interact with the protein phase during coagulation. Pockets of serum phase, which appear as black areas, are also observed in the micrograph. The gross chemical composition of this product was the following: $120 \mathrm{~g} \cdot \mathrm{kg}^{-1}$ fat, $210 \mathrm{~g} \cdot \mathrm{kg}^{-1}$ protein and $380 \mathrm{~g} \cdot \mathrm{kg}^{-1}$ dry matter.

Figure $6 \mathrm{C}$ shows the microstructure of a whipped cheese. The composition of this commercial cheese was $250 \mathrm{~g} \cdot \mathrm{kg}^{-1}$ fat,
$65 \mathrm{~g} \cdot \mathrm{kg}^{-1}$ protein and $385 \mathrm{~g} \cdot \mathrm{kg}^{-1}$ dry matter. Two main supramolecular structures of milk fat were observed. They correspond to (i) small fat globules $(\sim 0.5 \mu \mathrm{m})$ entrapped in protein aggregates, (ii) fat globules dispersed in the serum. The very small fat globules entrapped in the protein aggregates led to the superposition of white and red colours corresponding respectively to the staining of protein and fat. In this kind of product, the phase which appears in black in the micrograph may correspond to both the air and serum phases.

This study shows that the supramolecular structure of milk fat in cheese depends on the technology applied. Milk fat can be organised as (i) native fat globules, (ii) aggregates of fat globules, (iii) small fat globules which may be the result of homogenisation, (iv) coalesced fat globules, (v) free fat, or (vi) a combination of different phases and structures (Fig. 7).

\section{DISCUSSION}

Our results were similar to those previously obtained by Walstra [5] regarding the size $\left(d_{43}=4.07 \mu \mathrm{m}\right)$ and the specific surface area $\left(\mathrm{S}=7.1 \mathrm{~m}^{2} \cdot \mathrm{g}^{-1}\right.$ fat $)$ of natural milk fat globules in raw milk. Mulder and Walstra [8] estimated that small natural fat globules with $d<1 \mu \mathrm{m}$ comprise about $80 \%$ of the number of fat globules, but only a few percent of the total fat volume. Comparing the size of milk fat globules in raw milk and drinking milks, the results obtained in this study show important differences. The average fat globule sizes measured for UHT and pasteurised milks were lower than $0.7 \mu \mathrm{m}$, whatever the concentration of fat. This value was lower than the size of native milk fat globules; about $4 \mu \mathrm{m}$. Thus, the results obtained in this study confirmed that pasteurised and UHT milks are high-pressure homogenised products.

In many parts of the world, consumers can buy bovine milk from the farmer or in supermarkets as certified raw milk. However, fresh raw milk which comes straight 


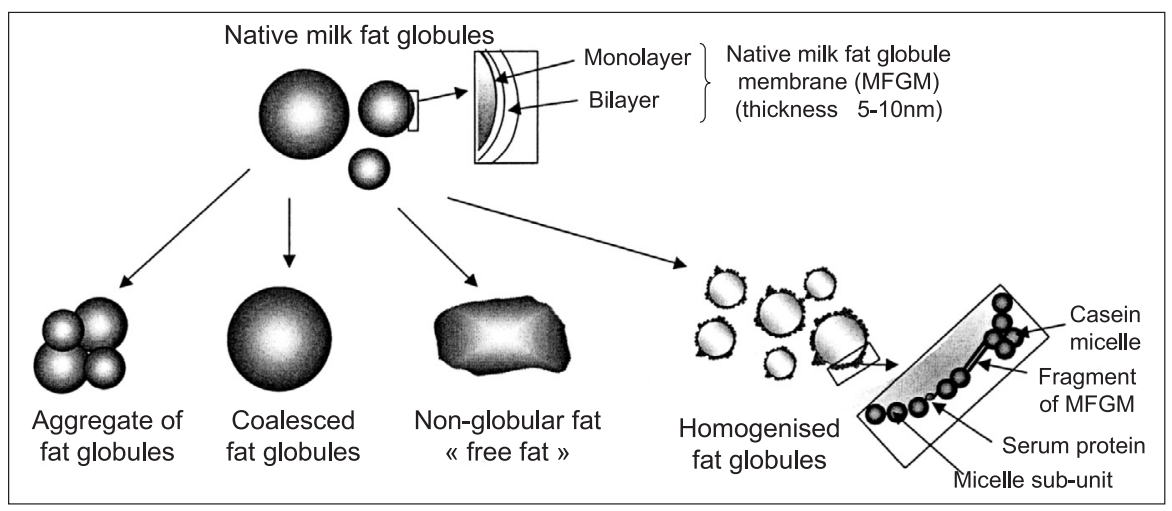

Figure 7. Schematic representation of the supramolecular structure of milk fat in dairy products (not to scale).

from the cow is hard to find nowadays. Milk is mainly transformed into drinking milks, which are at least homogenised and heat treated, or processed to obtain dairy products. Drinking milks, with their wide diversity (heat-treated or not, skimmed, semiskimmed or full fat, guaranteed vitamin content, etc.), are the widely consumed dairy product in France [20].

Milk, directly from the cow, is rarely consumed due to fears regarding possible microbiological risks and also the perception of increased fat intake, due to the fat layer that develops on the milk surface when left to stand. Thus, milk undergoes technological treatments. They are heat treated and homogenised to prevent their microbiological and physical instability, respectively.

Homogenisation is of special interest in the dairy industry in order to reduce the size of fat globules in milk and creams, and to prevent creaming and coalescence during long shelf-storage [11]. Homogenisation increases the interfacial surface area of fat in solution by increasing the number of fat globules. The increase in the fat surface area measured in this study was about 4 - to 8 -fold (Tab. I). Such a tremendous increase alters the membrane composition which can no longer cover the fat globules entirely and which may be partially lost in the serum phase. Thus, the newly formed interface suffers from a lack in membrane material to cover the surface. Adsorption of new material at the oil-water interface occurs to cover this increase in the surface area. The fraction $\Phi$ of the milk fat globule surface that is covered by milk proteins after processing of commercial milks was quantified in this study; it corresponded to 66-87\%. (Tab. I). The amount of fat globules with a diameter centred at about 100 and $500 \mathrm{~nm}$ in raw milk, increases in processed drinking milks. Part of these fat globules may be damaged during homogenisation, but these fat globules may also be newly formed "synthetic" milk fat globules. After homogenisation, the new membrane which surrounds fat globules, called synthetic FGM, consists of native MFGM plus adsorbed milk proteins, with casein as the dominant group and whey proteins, with mainly $\beta$-lactoglobulin [11, 12, 14, 24, 25]. Cano-Ruiz and Richter [25] reported that caseins represent about $70 \%$ of the proteins in the synthetic FGM and that approximately $10 \%$ of the proteins were from the native MFGM after homogenisation of the milk. These results were consistent with the results of Keenan et al. [14] who found that about $10 \%$ of the surface of homogenised fat globules in milk is 
covered by their native MFGM. McPherson et al. [26], who analysed the composition of membrane material isolated from commercial pasteurised homogenised milks and UHT milks, mainly found caseins and whey proteins. Their results are in agreement with studies performed with heat treated and homogenised milks. Considering the organisation of proteins, it has been shown that the milk fat globule surfaces were covered with (i) intact casein micelles, (ii) partially spread casein micelles, (iii) smaller particles, which probably result from the desintegration of casein micelles and (iv) a thin layer of proteins, which was probably whey proteins [27, 28]. The sequence of homogenisation and heating changes the structure and the composition of the synthetic FGM [25]. Houlihan et al. [29] found that heatdenaturated serum proteins interact with native MFGM proteins.

The synthetic FGM formed after homogenisation of milk have different characteristics and properties compared to the native MFGM. The composition and structure of this new membrane may be responsible for some of the observed differences between homogenised and non-homogenised milks. These include changes in the susceptibility of the product to $\mathrm{Cu}$ and light-induced flavour deterioration, a reduction in the creaming rate and changes in the colour and flavour characteristics [8].

Considering the characterisation of the supramolecular structure of fat in a complex matrix, the development of adequate protocols and the choice of non destructive methods is essential. It is important to highlight that the destabilisation of fat, which may occur during the manufacture of cheese, and the formation of free fat, which is the fat not protected by a membrane, does not allow the determination of the size of fat globules by laser light scattering. Thus, we chose the CLSM, which is a useful technique to characterise the supramolecular structure of fat in a complex matrix. CLSM is a powerful tool to penetrate the surface of a sample and to visualise thin optical sec- tions. The use of CLSM provides an opportunity to characterise milk fat globules in cheeses, without disturbing the internal structure [15-17, 30].

Regarding the structure of fat in dairy products, some elements are assumed. In milk, cream and yoghurt, fat is consumed as a direct emulsion with the fat globules being dispersed in the plasma phase: fat globules are covered by the MFGM, tiny homogenised fat globules are mainly covered by caseins. In butter, fat is consumed as a reverse emulsion in which water droplets are dispersed in the continuous partially crystallised fat phase. In cheese, the fat is dispersed in a protein network, but its supramolecular structure depends greatly on the process. In spite of the great significance of the physical structure of milk fat and the interactions between fat and proteins, regarding lipase activity and the functional properties, only a few authors have studied the organisation of fat in complex products.

This study showed that the milk fat globules are submitted to all the physical instabilities of oil in water emulsions, e.g. creaming, aggregation, coalescence. As a consequence, milk fat may be present in many products in different structures, as previously detailed in this study. These results were in agreement with Walstra [5], who found that many dairy products contain homogenised, recombined or destabilised fat, rather than natural milk fat globules. The surface of fat globules may be (i) the MFGM, (ii) caseins, (iii) serum proteins, (iv) amphiphilic molecules such as phospholipids and MFGM proteins, (v) a combination of MFGM and milk proteins. Considering more precisely the cheeses, milk fat may have similar physico-chemical properties as in raw milk, i.e. globules with $d \sim 4 \mu \mathrm{m}$ and the presence of the MFGM, in soft cheeses such as Camembert.

Depending on the composition of the interface, e.g. MFGM, monolayer of phospholipids, caseins, serum proteins or other 
proteins, milk fat interacts differently with the protein matrix in which it is entrapped, leading to specific rheological properties of gels [31-33]. Furthermore, both the supramolecular structure of fat, e.g. non-globular or globular with various sizes, and the composition of the interface, e.g. MFGM, caseins, may influence the diffusion of molecules (minerals, lactacte, ...) in the cheese matrix.

The role of fat globules on the functionality of different kinds of cheeses, such as Cheddar and Mozzarella cheese has been explored but is still not fully understood. Gunasekaran and Ding [15] examined, using CLSM, the three dimensional characteristics of fat globules in one month old Cheddar cheese of varying fat contents. Guinee et al. [16] also examined the microstructure of Cheddar cheeses. The size of the fat globules and their dispersion in the casein matrix of Mozzarella cheese has been shown to be related to meltability and free-oil formation [34]. Furthermore, it has recently been shown in our laboratory that the size of native milk fat globules affects the physico-chemical and functional properties of Emmental cheese [19] and Camembert cheese [18]. Furthermore, foaming and whipping are strongly affected by properties of the milk fat globules and the properties of high-fat products may especially be dominated by those of the milk fat [5].

Sensory properties of milk fat have long been recognised and considered of importance. Fat content and emulsion characteristics have a marked influence on the texture, melting and mouthfeel, of most dairy products [21]. Moreover, milk fat influences the flavour of dairy products. The majority of flavour compounds are at least partially soluble in fat, suggesting that the fat acts as a reservoir for flavour compounds. Thus, the supramolecular structure of fat may facilitate flavour generation by providing a fat-protein interface for flavour-producing reactions to occur. Furthermore, the perception of fat in dairy products and the release of flavour compounds may depend on (i) the concentration of fat in the product, (ii) the supramolecular organisation of fat in the product, e.g. free fat or globular fat and (iii) the composition and the structure of the surface covering the fat.

Microstructural and physicochemical dynamics of fat globules in cheese appear to influence the localisation and retention of starter lactococci in cheese [35]. However, to date, no detailed scientific investigation has been undertaken to elucidate the mechanism of accessibility of fat in cheese for lipolysis [36]. The enzymatic hydrolysis of fat, e.g. lipolysis, may be influenced by (i) the interfacial surface area of fat and (ii) the accessibility of fat to enzymes. Since lipases are active on emulsified substrates, the specific surface area of the milk fat globules plays an essential role in lipolysis. The interfacial surface area of fat in a dairy product depends on (i) the supramolecular organisation of fat: non-globular fat, globular fat and on (ii) the size of the milk fat globules: for a defined concentration of fat, the lowest is the size of fat globules, the largest is the interfacial area. Reducing the size of fat globules by homogenisation makes the fat more susceptible to fat hydrolysis by means of lipase enzymes; Homogenisation is widely used to make blue cheese in order to enhance lipolysis. Moreover, the accessibility of fat to enzymes may depend on the composition of the surface covering the fat. It is known that the MFGM, in which are enveloped natural milk fat globules, is a natural physical barrier against lipolysis. Coalesced fat globules, resulting from the fusion of natural milk fat globules of smaller size are enveloped by the MFGM. Homogenised fat globules are enveloped by the MFGM and milk proteins, mainly the caseins. The free fat is not protected by the MFGM but the interface may be constituted by amphiphilic molecules such as (i) the primary membrane of the MFGM, (ii) fragments of the MFGM, (iii) phospholipids coming from the MFGM and (iv) proteins.

Dairy products are widely consumed during meals and considering the enzymatic hydrolysis of fat during the digestion 
process, it may be possible that the supramolecular structure of milk fat and its environment (minerals, proteins) in dairy products may affect its digestibility and nutritional properties.

\section{CONCLUSION}

Bovine raw milk is the milk coming straight from the farm before it is processed. The supramolecular structure of fat in raw milk is the milk fat globule $(\sim 4 \mu \mathrm{m})$, enveloped in the specific biological membrane (the MFGM). Native milk fat globules dispersed in fresh raw milk are the starting point for many dairy products but are rarely consumed.

At the dairy factory, raw milk is made into dairy products including drinking milk, creams, ice cream, yoghurt, butter, dairy desserts and all kinds of cheeses. The relative fat content of dairy products varies enormously, from less than $0.5 \%$ in skimmed milk and low-fat products through upwards of $82 \%$ in butter. Due to dairy processes of milk, the structure of fat is greatly modified and the MFGM is damaged or absent in most dairy products. High pressure homogenisation of milk, which is the most widely used mechanical process, induces a decrease in the size of fat globules and changes in the composition of the membrane stabilising the milk fat globules.

In this study, CLSM permitted the investigation of the organisation of fat in a complex protein matrix, such as cheese. We showed that milk fat can be organised as: (i) fat globules covered by the MFGM, (ii) coalesced fat globules covered by the MFGM, (iii) tiny homogenised fat globules, with $\mathrm{d}<4 \mu \mathrm{m}$, mainly covered by caseins, (iv) aggregates of fat globules, (v) non-globular fat (free fat). Natural milk fat globules, "synthetic" fat globules and non-globular fat have different physicochemical membrane composition. Due to differences in the composition and structure of the interface, milk fat may have dif- ferent properties regarding the interactions with the protein matrix and the retention of water. Thus, the supramolecular structure of fat in dairy products may influence sensorial, functional and nutritional properties.

\section{ACKNOWLEDGEMENTS}

The author would like to thank R. Primault (Microscopy department, University Rennes I) and M.-N. Madec for technical assistance in CLSM and light microscopy, respectively. A. Ayerbe and ARILAIT Recherches are acknowledged for the analysis done on the consumption of milk fat in France as well as for valuable discussions.

\section{REFERENCES}

[1] Gurr MI. Nutritional significance of lipids. In: Fox PF (Ed), Advanced dairy chemistry, Vol 2, Lipids, 2nd ed, Chapman \& Hall, 1995, p 349-402.

[2] Jensen RG, Blanc B, Patton S B. Particulate constituents in human and bovine milk. In: Jensen R.G. (Ed), Handbook of milk fat composition, Academic Press, New-York, 1995 , p 50-62.

[3] Christie WW. Composition and structure of milk lipids. In: Fox PF (Ed), Advanced dairy chemistry, Vol 2, Lipids, 2 nd ed, Chapman \& Hall, 1995, p 1-32.

[4] Jensen RG, Newburg DS. Bovine milk lipids. In: Jensen RG (Ed) Handbook of milk composition, Academic Press, Inc, New-York, 1995, p 542.

[5] Walstra P. Physical chemistry of milk fat globules. In: Fox PF (Ed), Advanced dairy chemistry, Vol 2, Lipids, 2nd ed, Chapman \& Hall, 1995, p 131-178.

[6] Gresti J, Burgaut M, Maniongui C, Bezard J. Composition of molecular species of triacylglycerols in bovine milk fat. J Dairy Sci 1993, 76, 1850-1869.

[7] McPherson AV, Kitchen BJ. Reviews of the progress of dairy science; the bovine milk fat globule membrane. Its formation, composition, structure, and behaviour in milk and dairy products. J Dairy Res 1983, 50: 107133.

[8] Mulder H, Walstra P. In: The milk fat globule, Center for Agricultural publishing and documentation, Wageningen, The Netherlands, 1974. 
[9] Keenan TW, Dylewski DP. Intracellular origin of milk lipid globules and the nature and structure of the milk lipid globule membrane. In: Fox PF (Ed), Advanced dairy chemistry, Vol 2, Lipids, Chapman \& Hall, London, UK, 1995, p 89-130.

[10] Danthine S, Blecker C, Paquot M, Innocente N, Deroanne C. Evolution des connaissances sur la membrane du globule gras: synthèse bibliographique. Lait 2000, 80: 209-222.

[11] Walstra P, Jenness R. In: Dairy Chemistry and Physics, John Wiley \& sons Publ Inc, New York, NY, 1984.

[12] Sharma SK, Dalgleish DG. Interactions between milk serum proteins and synthetic fat globule membrane during heating of homogenized whole milk. J Agric Food Chem 1993, 1407-1412.

[13] Kim HHY, Jimenez-Flores R. Heat-induced interactions between the proteins of milk fat globule membrane and skim milk. J Dairy Sci 1995, 78: 24-35.

[14] Keenan TW, Moon TW, Dylewski DP. Lipid globules retain globule material after homogenisation. J Dairy Sci 1983, 66:196-203.

[15] Gunasekaran S, Ding K. Three dimensional characteristics of fat globules in cheddar cheese. J Dairy Sci 1999, 82: 1890-1896.

[16] Guinee TP, Auty MAE, Fenelon MA. The effect of fat content on the rheology, microstructure and heat-induced functional characteristics of Cheddar cheese. Int Dairy J 2000, 10: 277-288.

[17] Rowney MK, Roupas P, Hickey MW, Everett DW. The Effect of Compression, Stretching, and Cooking Temperature on Free Oil Formation in Mozzarella Curd. J Dairy Sci 2003, 86: 449-456.

[18] Michalski MC, Gassi JY, Famelart MH, Leconte N, Camier B, Michel F, Briard V. The size of native milk fat globules affects physico-chemical and sensory properties of Camembert cheese. Lait 2003, 83: 131-143.

[19] Michalski MC, Camier B, Briard V, Leconte N, Gassi J., Goudedranche H, Michel F, Fauquant J. The size of native milk fat globules affects physico-chemical and functional properties of Emmental cheese. Lait 2004, 84: 343-358.

[20] Centre National Interprofessionnel de l'Économie Laitière, L'économie laitière en chiffres, éd 2004, Paris, 2004.

[21] Mela DJ, Raats MM. In: Fox PF (Ed), Advanced Dairy Chemistry, Vol 2, Lipids, Chapman \& Hall, 1994, p 403-432.

[22] Jaros D, Petrag J, Rohm H, Ulberth F. Milk fat composition affects mechanical and rheological properties of processed cheese. Appl Rheol 2001, 11: 19-25.
[23] Lopez C, Camier B, Gassi JY. Evolution of the milk fat microstructure during the manufacture and ripening of Emmental cheese observed by confocal laser scanning microscopy. Submitted to Int Dairy J, December 2004.

[24] Darling DF, Butcher DW. Milk-fat globule membrane in homogenised cream. J Dairy Res 1978, 45: 197-208.

[25] Cano-Ruiz ME, Richter RL. Effect of homogenization pressure on the milk fat globule membrane proteins. J Dairy Sci 1997, 80: 2732-2739.

[26] McPherson AV, Dash MC, Kitchen BJ. Isolation and composition of milk fat globule membrane material. II. From homogenized and ultra heat treated milks. J Dairy Res 1984, 51: 289-297.

[27] Sharma R, Singh H, Taylor MW. Composition and structure of fat globule surface layers in recombined milk. J Food Sci, 1996, 61: 28-32.

[28] Hillbrick GC, McMahon DJ, McManus WR. Microstructure of indirectly and directly heated ultra-high temperature (UHT) processed milk examined using transmission electron microscopy and immunogold labelling, Lebensm Wiss Technol 1999, 486-494.

[29] Houlihan AV, Goddard PA, Kitchen BJ, Masters CJ. Changes in structure of the bovine milk fat globule membrane on heating whole milk. J Dairy Res 1992, 59: 321-329.

[30] Blonk JCG, van Aalst H. Confocal scanning light microscopy in food research. Food Res Int 1993, 26: 297-311.

[31] Xiong YL, Kinsella JE. Influence of fat globule membrane composition and fat type on the rheological properties of milk based composite gels. II. Results. Milchwissenschaft 1991, 46: 207-212.

[32] Lopez C, Dufour E. The composition of the milk fat globule surface alters the structural characteristics of the coagulum. J Colloid Interface Sci 2001, 233: 241-249.

[33] Michalski MC, Cariou R, Michel F, Garnier C. Native vs. damaged milk fat globules: membrane properties affect the viscoelasticity of milk gels. J Dairy Sci 2002, 85: 2451-2461.

[34] Rowney M, Roupas P, Hickey M, Everett DW. Milkfat structure and free oil in mozzarella cheese. Aust J Dairy Technol 1998, 53: 110.

[35] Laloy E, Vuillemard JC, El Soda M, Simard $\mathrm{RE}$. Influence of the fat content of Cheddar cheese on retention and localization of starters. Int Dairy J 1996, 6: 729-740.

[36] Collins YF, McSweeney PLH, Wilkinson MG. Lipolysis and free fatty acid catabolism in cheese: a review of current knowledge. Int Dairy J 2003, 13: 841-866. 